perience and fund of illustration possessed by Mr. Darwin, and I have to say that I am unconvinced by the arguments he has adduced. With the transparent frankness of all his writings, Mr. Darwin, in one of the references to which he has commended me, has collected a very large number of examples that tell very strongly against him, and which I again commend to $\mathrm{Mr}$. Wallace. I refer to the 18 th chapter of Mr. Darwin's book on the "Variation of Plants and Animals under Domestication," and especially to that portion beginning on page I49. In speaking of animals, he says :- " The most remarkable cases, however, are afforded by animals kept in their native country, which, though perfectly tamed, quite liealthy, and allowed some freedom, are absolutely incapable of breeding. Rengger, who in Paraguny particularly attended to this subject, specifies six quadrupeds in this condition, and he mentions two or three others which most rarely breed. Mr. Bates, in his admirable work on the Amazons, strongly insists on similar cases, and he remarks that the fact of thoroughly tamed wild animals and birds not breeding when kept by the Indians, cannot be wholly accounted for by their negligence or indifference, for the turkey is valued by them, and the fowl has been adopted by the remotest tribes. In almost every part of the world, for instance, in the interior of Africa, and in several of the Polynesian islands, the natives are extremely fond of taming the indigenous quadrupeds and birds, but they rarely or never succeed in getting them to breed," and so on, through sixty pages of closely-packed examples. And what is Mr. Darwin's commentary on these facts? I again quote page 158:- "We feel at first naturally inclined to attribute the result to loss of health, or at least to loss of vigour, but this view can hardly be admitted when we refiect how healthy, long-lived, and vigorous many animals are under captivity; such as parrots and hawks when used for hawking, chetahs when used for hunt ing, and elephants. The reproductive organs themselves are not diseased, and the diseases from which animals in menageries usually perish are not those which in any way affect their fertility. No domestic animal is more subject to disease than the sheep, yet it is remarkably rert:le." Mr. Darwin, with equal clearness and conclusiveness, decides that this sterility cannot be dus to a fallure of sexual instincts, change of clmate or of food, or want of food or exercise; and be concludes that certain changes of habits and of life affect in an inexplicable manner the powers of reproduction. But what is true of man it is reasonable to suppose is true of all these instances-namely, that it is a more luxuriods habit, a more vigorous health. a less precarious existence, induced by the care and attenition of domesticators, that have caused the sterility; that these animals are too well off, and not that they are ill of in any way; and this theory explains the whole m'sst conclusively. On the o her hand, and in opposition to this vast and unifurm collection of examples, Mr. Darwin adduces a few instances which tell the other way, but they are very fow in number, and seem to me explicable on other grounds. Ferrets, it is notorious, arealways kept in a state of extreme depletion and as thin as possible. Domesric poultry are fed almost entirely on poor vegetable food, while their wild and semi-wild relatives feed much more on worms, insects, and on animal diet generally. In regard to sheep, it is notorious that very weak ewes generally bear twins, that Somersets and Dorsets are more fertile than Southdowns and Leicesters. We have, I may add, $\mathrm{no}$ facts to guicle us in regard to wild dogs, and few in regard to wild cats; but we do know that in tame ones the half-fed lantern-ribbed curs are more prolific than their sleek relations. In regard to domestic fowls, and especially pigeons, we must remember that their condition is materially altered by the disuse or only very partial and irregular use of their powers of flight, this must reduce their circulation and vigour very considerably, and make them pro tanto so mul weaker. But these instances, upon which Mr. Darwin relies to answer Doubleday and others, are very partial indeed. In his own pages, as I have already said, they form a very small element compared with the overwhelming cases he quotes on the other side. So much so, indeed, that these cases may be taken as exceptions which prove the rule that domestication and improved conditions of life induce sterility in animals.

It savours of scholastic philosophy to speak of Nature as exercising any influcnce on the regeneration of races, and yet there may be sorund philosophy in the old notion that when an individual or a class is in danger of being excinguished from want, Nature puts forward a special effurt to preserve it. The sickly mother, the half-starved plant, is more likely to breed than the healthy and the vigorous. If we remove the peasant's family to the drawing room, it will cease to be com. posed of ten and twelve children. If we remove our daisies and cowslips to the greenhouse, their flowers grow double, and they ripen no seeds. The vine that has felt the frost is the one to pay the rent. Wherever we turn, in fact, we meet with examples of the universal law; and this law seems to be at issue with an important portion of Mr. Darwin's theory, namely, that in the struggle for existence, the vigorous, the hearty, and the well-to-do, elbow the weak and decrepid until they elbow them out of existence, and supplant them. If I have said anything above which can be construed into an impertinence, I unconditionally withdraw it. The only excuse for soreness, is an impatiense at what seems to the writer to be indefensible dogmatist:. The days will not be ripe for scientific dogmatism until the Infallibility of Positive Philosophers has been generally accepted, and it does not do to forestal that millennium.

H. HOWORTH

Mr. Waldace his effeciually set aside Mr. Howorth's new views on Darwinism, and it now only remains to point out that the latter gentleman, in his instances, puts the cart before the horse. Hens that are fat and don't lay are fat because they don't lay. When the sexual powers, either in plants or animals, are defective from accident or design, the overgrowth always takes place, and this among animals is chiefly by the increase of adipose tissue.

Birmingham

LAWSON TAIT

\section{Recent Neologisms}

I HAVE been long accustomed to register the first appearance of new words and phrases. Of course the vast majority of these take no root, perishing whre they fall. Here is a sample of the latest issue: Survizal, introduced, I think, by Darwin ; indiscipline and impolucy, which were brought in by tise Franco-Prussian War, and also the vulgarism to telegrom. The greatest atrocities in th:s line are committed by "physicists," if the shade of Faraday wi:l pardon me the use of that word; and far away the worst coinage I cver encountered is due to Mr. Alfred $R$. Wallace. As it is "meet and right and our bounden duty" to stigmatise such intruders, and if possible prevent their adoption, I take the liherty of making my feeble protest against Mr. Wallace's "prolificness," which he introduces to our no!ice in his letter on Mr. Howorth (NATIRE, July 6, I87I, p. I8I). In this case the hideousness of tive coinage is some guarantee against its reception. Malvern Wells, July 8

C. M. INGLEBY

\section{Affinities of the Sponges}

I HAVE just read with much interest the paper in NATURE by Mr. W. Saville X $\_n t$, criticising my friend Carter's article in the "Annals of Natural History" for this month, in which I fully concur. How Mr. Carter can have fallen into such an error, for such I must call it, I cannot imagine, as comparing a group of animals in Botryllus to those sponge cells, even in so highly a developed form as Grantia. For, taking this as the highest known form of sponge animal, it is at most only a monociliated sac, as shown both by Prof. Clark and by Mr. Carter. Now, it is well known to all investigators, and Mr. Carter has shown it himself, that the animals of Botryllus have distinct oral and fæcal aper* tures, whereas the sponge cell, so far as has yet been seen, has only an oral aperture. Again, the Ascidian Botryllus is shown to be far higher in the scale when we come to compare its internal organisation, and not merely to confine ourselves to the sac-like tunic. The discharge of the frecal matter into a common cloacal canal is to me not a sufficient reason for comparing these groups of animals to the sponge animals in Grantia.

But what I wish to draw attention to more particularly is this, that in the hurry and bustle of our investigators of the present day, all old associations are mostly, if not entirely, forgotten. I can scarcely think that they are ignored, but are forgotten. Thus, Prof. Grant was, I believe, the first to determine the character and the full importance of the seed-like body in Hallchondria by placing watch-rlasses in the vessel in which living specimens of the above sponge was placed; the bodies were thus discharged from the facal canal of the parent sponge, and attached themselves to the watch-glasses, and he then carefully watched their development. Mr. Carter, being a pupil of Dr. Grant, no doubt followed his teacher's plan of investigation, which has led to the brilliant results of this gentleman's in. 